\title{
Analysis of Alternative Purification of Beta-Propiolactone Inactivated, Tangential Flow Filtration Concentrated Vero Cell Derived Rabies Vaccine
}

\author{
Jagannathan Selvaraj ${ }^{{ }^{*}}$, Mani Kavaratty Raju ${ }^{2,3}$ and Vijayakumar Rajendran ${ }^{4}$ \\ ${ }^{1}$ Department of Tissue Culture Anti-Rabies Vaccine Section (TCARV), Pasteur Institute of India, Coonoor, TheNilgiris, Tamilnadu, 643103, India \\ ${ }^{2}$ Former Deputy Director, Pasteur Institute of India, Coonoor, The Nilgiris, Tamilnadu, 643103, India \\ ${ }^{3}$ Former Director, Central Research Institute, Kasauli, Solan, Himachal Pradesh, 173204, India \\ ${ }^{4}$ Department of Biochemistry, North Eastern Hill University, Shillong, Meghalaya, 793022, India
}

"Corresponding author: Jagannathan Selvaraj, Department of Tissue Culture Anti-Rabies Vaccine Section (TCARV), Pasteur Institute of India, Coonoor, The Nilgiris, Tamilnadu, 643103, India, Tel: +9194860 81990; E-mail: seljag2005@yahoo.com

Received date: 11 November 2014; Accepted date: 27 January 2015; Published date: 29 January 2015

Copyright: $\odot 2015$ Selvaraj J, et al. This is an open-access article distributed under the terms of the Creative Commons Attribution License, which permits unrestricted use, distribution, and reproduction in any medium, provided the original author and source are credited.

\begin{abstract}
Rabies virus is a single stranded negative sense RNA virus that belongs to the genus lyssavirus of the rhabdoviridae family which causes an acute disease of vertebrate animals. In the production of vaccines, purification plays a crucial role in the vaccine efficacy. Viral inactivation and removal steps are critical parts in mammalian cell culture derived biotechnology products. Regulatory agencies are concerned with the presence of endogenous or adventitious agent in the cell lines or raw materials employed to manufacture pharmaceuticals protein from cell culture. Due to this, numerous techniques are affianced in the downstream processing of viral vaccines manufacturing especially chromatography. Advances in vaccine manufacturing have created an increasing demand for large volumes of highly purified viral antigens. Cellufine sulfate Chromatography which has been used for other viral vaccines of both animal and human, was used in this study for optimal recovery of valuable rabies viral protein and optimal removal of impurities such as residual cellular DNA and host cellular BSA successfully as a replacement of the existing zonal centrifuge method.
\end{abstract}

Keywords: Rabies; Chromatography; Cellufine sulfate; Residual DNA

\section{Abbreviations \\ SRID: Single Radial Immunodiffusion Assay, TFF: Tangential Flow Filtration; ODD: Ouchterlony Double Immunodiffusion; HCP: Host Cellular Protein; HAU: Heamagglutination Unit}

\section{Introduction}

During the production of viral vaccines the chromatographic techniques are vital part in protein purification; final product of these technique should be free from contaminants with higher purity. Selection of appropriate chromatographic matrix is very much reliant to the physiochemical attributes of target product. For the large scale downstream purification the flow rate plays a main role, it is more significant to other parameters [1]. The gram negative bacterial spores outer membranes (endotoxin) represents a major potential contaminant, which may cause nonspecific, their exclusion from immunobiological products, through apt purification procedures represents a major assignment of vaccine manufacturing process [2]. The Cellufine matrix was used for various proteins purification like Respiratory syncytial virus (RSV) and vesicular stomatitis virus (VSV) [3], Helicobacter pylori urease enzyme [4].

The cell cultured-derived rabies vaccines were developed to replace the conventional nerve tissue vaccines (NTVs), although the cell culture vaccine are safer and more efficacious than the reactogenic NTVs. Presently sucrose gradient zonal centrifugation is widely used, accepted for large scale production of cell culture derived rabies vaccines; the vaccine produced by this method is high in quality, safe and effective. Vero cells used as substrate for the multiplication of rabies virus leaves residual cellular DNA and animal serum as contaminants, these have to be effectively removed from the vaccine for its safety concern. The influencing factors like manpower consumption, more raw materials utilization, and total equipment dependency, it is difficult to control over the parameters constitute a cumbersome process of existing zonal centrifugation. Therefore the objectives of the present study is to purify vero cell based human rabies vaccine using a well-standardized procedure based on several experiments so as to achieve maximum purification and comply with IP/WHO requirements for residual cellular DNA and HCP content without the antigenicity loss.

\section{Materials and Methods}

\section{Cells and virus}

Vero cells (CCL-81) were obtained from ATCC at the passage number 125 as monolayer frozen cells and propagated with appropriate medium [5]. Further it was revived, sub cultured and seeded into roller bottles $\left(2.5 \times 10^{-6}\right.$ cells $\left./ \mathrm{mL}\right)$ with serum containing medium (SCM) and serum free medium (SFM) [6]. Further the cultures were incubated at $37^{\circ} \mathrm{C}$ with rpm of $0.6 \mathrm{rpm}$. Fixed strain of Pasteur virus (PV-11) was obtained from Institute Pasteur France and it was propagated, infected with monolayer vero cell line and the virus infectivity was analyzed [5,7]. The rabies infected vero cell supernatant (viral harvest) was collected and replenished with maintenance medium which contains only essential and non-essential amino acids along with meager amount of newborn calf serum which is for only in 
Page 2 of 6

the function of maintaining the cell viability without cell proliferation. The challenge virus stranded strain was propagated in mouse brain and then titrated, it was used for RFFIT and intracerebral rabies virus challenge. At every interval of 72 hrs for 5 harvests, infectivity in mice (LD50) was analyzed by in vivo through inoculating increasing dilutions of the virus material to Swiss albino and based on mortality in different dilutions [8] and viral titer was calculated [9].

\section{Concentration and inactivation of rabies virus}

Those viral harvests which have passed the in process quality control tests subsequently process for tangential flow ultrafiltration $(\mathrm{CON}), \beta \mathrm{PL}$ inactivation [5], the SCM and SFM originated rabies virus, $\beta \mathrm{PL}$ inactivated concentrate was tested for its status by in vivo and in vitro method [10].

\section{Purification strategy of rabies virus}

Matrex $^{\oplus}$ Cellufine ${ }^{\text {twx }}$ Sulfate (Millipore) was used as media for affinity chromatography purification, which was immobilized with $100 \mathrm{mM}$ of $\mathrm{NaCl}$ in 10 mM PBS (buffer A), pH 7.6. For purification step gradient buffers used with increasing concentration of $\mathrm{NaCl}$ (300 (buffer X), 600 (buffer B), $1200 \mathrm{mM}$ (buffer C) and $1800 \mathrm{mM}$ (buffer D)) $10 \mathrm{mM}$ PBS, pH 7.6 was used. The diameter and height of the column was 11 $\mathrm{mm}, 250 \mathrm{~mm}$ respectively, the I.D/O.D of the flow tubes are $1 \mathrm{~mm} / 1.6$ $\mathrm{mm}$, the bed support was 10 micron polypropylene layer. The Cellufine sulfate was loaded and packing flow rate was maintained until reaching the bed heights $(6,7,8,9$, and $10 \mathrm{~cm})$ used with matrix in different volume such as $12.5,14.3,15.6,17.1$ and $18.7 \mathrm{~mL}$, all the experiments were conducted in ambient temperature. In SCM originated rabies viral, the protein concentration was $473 \mu \mathrm{g} / \mathrm{mL}$, mouse infective titer was $10^{-4.5}$, no visible zone between rabies antigen and antibodies were found in SRID, the HCP and Residual cellular DNA were $500,10 \mathrm{ng} / \mathrm{mL}$, respectively, the CON was further diluted with buffer A prior to loading. In each experiment 15 fractions were collected, step recovery was calculated. The eluted fractions were pooled and desalted by diafiltration.

\section{Formulation and Quality attributes of rabies virus}

The desalted proteins are formulated with human albumin and maltose as and it was subjected to their quality attributes, sterility test, $\mathrm{pH}$, abnormal toxicity, and innocuity was done [5]. The single human dose was used for immunogenicity analysis. The total protein was measured by using BCA Protein Assay Kit [11]. The HA test was done as per the technique described by Kuwert et al. with modifications; the end point result was taken by the highest virus dilution giving detectable HA [12]. The HA was expressed in HA units by calculating the $50 \%$ end point using the formula for $0.2 \mathrm{~mL}, 300 \mu \mathrm{l}$ of eluted fractions was analyzed its purity (OD 260/280), and structural stability (SDS) $[13,14]$.

The immune sera's of guinea pig were confirmed by ODD, Rapid Flourescent Focus Inhibition Test (RFFIT) and SRID [15,16], for the raising of guinea pig immune sera's, the healthy guinea pigs are immunized with cellufine sulfate purified selected eluted fractions, formulated were immunized with Freund's complete adjuvant on $7^{\text {th }}$ and $14^{\text {th }}$ day, on the $21^{\text {st }}$ day bloods were collected and serums are separated. Local reference vaccine (zonal centrifuged) which calibrated against WHO standard vaccine, was used as standard for all tests.

The HCP was quantified by ELISA method, DNA was extracted by phenol-chloroform method, the amount of control DNA was estimated by monitoring the absorbance at A260 and A280. The extracted control DNA and test sample DNA were subjected for blotting. Seven different concentrations (10, 5, $1 \mathrm{ng}, 800,400,200$ and $100 \mathrm{pcg}$ ) were used as control blotting of vero cell DNA, hybridization with test samples and detection was done [17].

\section{Results and Discussions}

\section{Optimization of laboratory scale chromatography for rabies virus purification}

The concentrated, BPL inactivated rabies viral harvests were further purified with Cellufine sulfate packed column chromatography on experimental basis. When the matrix column of $8 \mathrm{~cm}(15.6 \mathrm{ml}$ of bed volume of matrix) was used, in case of purification peak analysis impurities were found to the symmetry, indicating the maximal recovery of viral antigen and the removal of maximal quantity of impurities, for the purification of $\mathrm{P}$ or B from Nesseria meningitidis they are used linear gradient buffer and the purity is higher in status [18]. The complete profile of affinity chromatography using cellufine sulfate is presented in Figure 1. The majority of impurities like HCP, cell metabolites, and host cell- DNA that not bound with matrix during adsorption with buffer A. Total of 15 eluted fractions were collected, Fractions, 1 to 6 corresponds to buffer A, 7 and 8 corresponds to buffer X, Fraction 9 and10 corresponds to buffer B, fractions 11 and 12 corresponds buffer $\mathrm{C}$ the remaining fractions 13,14 and 5 correspond to buffer $\mathrm{D}$, each fractions are analyzed for OD at $260 / 280 \mathrm{~nm}$. The peak analysis of viral protein recovery and the removal of impurities had the symmetrical peak, as reflected in the A260/A280, further it was confirmed with SRID unitage Table 1. Two isolates of street rabies virus were found to have elution points at $0.2 \mathrm{M}$ and $0.3 \mathrm{M} \mathrm{Kcl}$ respectively in the type $20 \mathrm{CM}$-cellulose and type 20 standard grade DEAE celluloses purification an increasing the salt concentrations to $0.5 \mathrm{M} \mathrm{KCl}$ reduced trailing and resulted in higher titter of the street viruses [19].

\begin{tabular}{|l|l|l|l|l|l|l|}
\hline $\begin{array}{l}\text { Height of } \\
\text { the } \\
\text { Matrix }\end{array}$ & $\begin{array}{l}\text { Volume of } \\
\text { the matrix } \\
\mathbf{m l}\end{array}$ & $\begin{array}{l}\text { NaCl } \\
\text { strength } \\
\text { (Elution) }\end{array}$ & $\begin{array}{l}\text { Peak } \\
\text { analysis }\end{array}$ & $\begin{array}{l}\text { OD at } \\
\mathbf{2 6 0} \\
\mathbf{n m}\end{array}$ & $\begin{array}{l}\text { OD at } \\
\mathbf{2 8 0} \\
\mathbf{n m}\end{array}$ & $\begin{array}{l}\text { SRID } \\
\text { Unitage }\end{array}$ \\
\hline $6 \mathrm{Cm}$ & 12.5 & $300 \mathrm{mM}$ & Symmetry & 0.0106 & 0.0249 & 4.4 \\
\cline { 3 - 7 } & & $600 \mathrm{mM}$ & Asymmetry & 0.1204 & 0.1773 & 4.64 \\
\hline $7 \mathrm{Cm}$ & 14.3 & $300 \mathrm{mM}$ & Symmetry & 0.2008 & 0.3175 & 6.5 \\
\cline { 2 - 7 } & \multirow{2}{*}{$800 \mathrm{mM}$} & Asymmetry & 0.2219 & 0.3228 & 7.1 \\
\hline \multirow{2}{*}{$8 \mathrm{Cm}$} & 15.6 & $300 \mathrm{mM}$ & Symmetry & 0.1904 & 0.1771 & 8.32 \\
\cline { 3 - 7 } & & $600 \mathrm{mM}$ & Symmetry & 0.1520 & 0.2238 & 7.1 \\
\hline \multirow{2}{*}{$9 \mathrm{Cm}$} & \multirow{2}{*}{17.1} & $300 \mathrm{mM}$ & Symmetry & 0.2669 & 0.2647 & 7.1 \\
\cline { 3 - 7 } & & $600 \mathrm{mM}$ & Asymmetry & 0.3881 & 0.3971 & 8.2 \\
\hline \multirow{2}{*}{$10 \mathrm{Cm}$} & 18.7 & $300 \mathrm{mM}$ & Symmetry & 0.2557 & 0.4243 & 8.32 \\
\cline { 3 - 7 } & & $600 \mathrm{mM}$ & Asymmetry & 0.3109 & 0.4849 & 8.2 \\
\hline
\end{tabular}

Table 1: Analysis of optimal bed height for rabies virus purification with Cellufine Sulfate. ${ }^{*}$ Results are the mean values of 3 separate experiments. 
Page 3 of 6

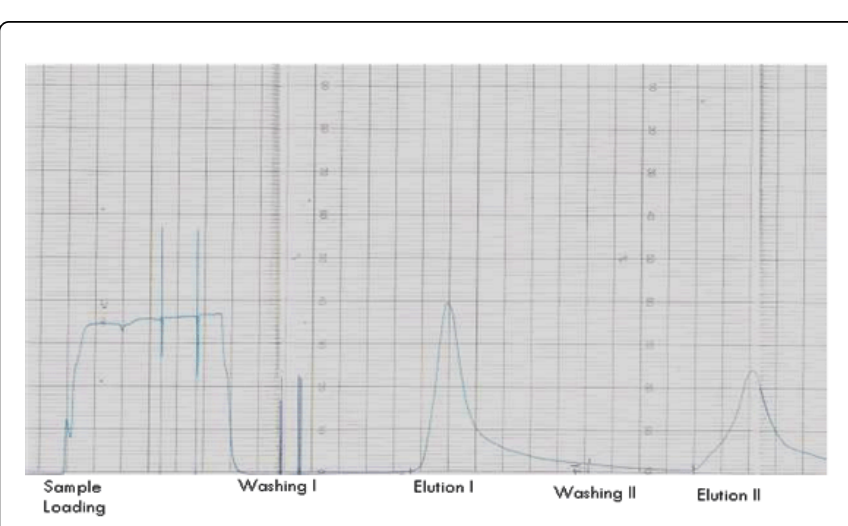

Figure 1: Chromatography of rabies viral proteins on Cellufine sulfate packed column washed with buffer A, eluted with buffer X and buffer B.

When the bed height was increased from $8 \mathrm{~cm}$ to $9 \mathrm{~cm}$ and $10 \mathrm{~cm}$ the elution peak from the viral antigen was symmetry but the elution peak for removal of the impurities was found to be asymmetry. The corresponding SRID unitage revealed that the concentration of impurities remained to be on the higher side (SRID unitage $8.23 \mathrm{IU} / \mathrm{ml}$ in each case) and required further removal in order to render the final rabies vaccine passing the quality control tests.

\section{Yield and recovery analysis of Rabies viral protein}

The quantum of rabies viral protein during primary run and secondary run on the pooled material from primary run fractions was given below the Table 2. During the elution with $\mathrm{X}$ and $\mathrm{B}$ the column was washed until it reaches the baseline. A total rabies viral protein of about $455 \mathrm{mg} / \mathrm{ml}$ was subjected to elution with $300 \mathrm{mM}, 600 \mathrm{mM}$ and $1200 \mathrm{mM}$ of $\mathrm{NaCl}$ in $10 \mathrm{~mm}$ of PBS. During the primary run the quantum of rabies viral protein recovery was found to be $87 \%, 10 \%$ and $0.37 \%$ respectively. However for maximal viral proteins, the optimal level of elution buffer was found to be $300 \mathrm{~mm}$.

\begin{tabular}{|l|l|l|l|l|}
\hline \multicolumn{5}{|c|}{ Primary run } \\
\hline & $\begin{array}{l}\text { Concentrated, } \\
\text { inactivated rabies vir } \\
\text { al protein }\end{array}$ & \multicolumn{3}{l|}{ Chromatographic fractions } \\
\cline { 3 - 5 } & $\mathbf{3 0 0 \mathrm { mm }}$ & $\mathbf{6 0 0} \mathbf{~ m m}$ & $\mathbf{1 2 0 0} \mathbf{~ m m}$ \\
\hline $\begin{array}{l}\text { Total protein } \\
\mathrm{mg} / \mathrm{ml}\end{array}$ & 455 & 398 & 47 & 1.7 \\
\hline Yield \% & $100 \%$ & $87 \%$ & $10 \%$ & $0.37 \%$ \\
\hline
\end{tabular}

Table 2: Rabies viral protein yield analysis in laboratory scale affinity chromatography. ${ }^{*}$ Results are the mean values of 3 separate experiments.

The HAU/0.2 $\mathrm{ml}$, total protein $\mu \mathrm{g} / \mathrm{ml}$, SRID unitage $\mathrm{IU} / \mathrm{ml}$, HCP $\mathrm{ng} / \mathrm{ml}$ and residual cellular DNA $\mathrm{ng} / \mathrm{ml}$ before and after purification are given in the table 3 and the values was found to be, $16.5 / 0.2 \mathrm{ml}, 37$ $\mu \mathrm{g} / \mathrm{ml}$, no visible zone, around $500 \mathrm{ng} / \mathrm{ml}$ and around $10 \mathrm{ng} / \mathrm{ml}$ respectively, for the concentrated material prepared out of SCM. After purification, these values were found to be in the order of $1442 / 0.2 \mathrm{ml}$, $736 \mu \mathrm{g} / \mathrm{ml}, 7.94 \mathrm{IU} / \mathrm{ml}, 32 \mathrm{IU} / \mathrm{ml}$, less than $10 \mathrm{ng} / \mathrm{ml}$ and around 0.01 $\mathrm{ng} / \mathrm{ml}$ respectively. In case of SFM the concentrated material had HAU $20 / 0.2 \mathrm{ml}$ and total protein was $39 \mu \mathrm{g} / \mathrm{mL}$; however the other values found to be same as in case of SCM. After purification these values were found to be $1532 \mathrm{HAU} / 0.2 \mathrm{~mL}, 755 \mu \mathrm{g} / \mathrm{mL}$ of total protein, $7.65 \mathrm{IU} / \mathrm{ml}$ of SRID unitage, less than $10 \mathrm{ng} / \mathrm{ml}$ of HCP and around $0.01 \mathrm{ng} / \mathrm{ml}$ of residual cellular DNA (Figure 2).

\begin{tabular}{|c|c|c|c|c|c|c|}
\hline \multirow{2}{*}{$\begin{array}{l}\text { Chromatography } \\
\text { Purification } \\
\text { Status }\end{array}$} & \multirow[t]{2}{*}{ Sample } & \multirow{2}{*}{$\begin{array}{l}\text { HAU } \\
\text { per } \\
0.2 \mathrm{ml}\end{array}$} & \multirow{2}{*}{$\begin{array}{l}\text { Total } \\
\text { protein } \\
\mu \mathrm{g} / \mathrm{ml}\end{array}$} & \multirow[t]{2}{*}{$\begin{array}{l}\text { SRID } \\
\text { Unitage }\end{array}$} & \multicolumn{2}{|c|}{$\begin{array}{l}\text { Level of } \\
\text { impurities }\end{array}$} \\
\hline & & & & & $\begin{array}{l}\text { Host } \\
\text { cellular } \\
\text { BSA }\end{array}$ & $\begin{array}{l}\text { Host } \\
\text { cellular } \\
\text { DNA }\end{array}$ \\
\hline \multirow[t]{2}{*}{ Before* $^{*}$} & $\begin{array}{l}\text { TCAR- } \\
\text { CON } \\
(\mathrm{SCM})\end{array}$ & 16.5 & 37 & $\begin{array}{l}\text { No } \\
\text { visible } \\
\text { zone }\end{array}$ & $\begin{array}{l}>500 \mathrm{ng} \\
/ \mathrm{mL}\end{array}$ & $\begin{array}{l}10 \\
\mathrm{ng} / \mathrm{mL}\end{array}$ \\
\hline & $\begin{array}{l}\text { TCAR- } \\
\text { CON } \\
\text { (SFM) }\end{array}$ & 20 & 39 & $\begin{array}{l}\text { No } \\
\text { visible } \\
\text { zone }\end{array}$ & $\begin{array}{l}>500 \mathrm{ng} \\
/ \mathrm{mL}\end{array}$ & $\begin{array}{l}10 \\
\mathrm{ng} / \mathrm{mL}\end{array}$ \\
\hline \multirow[t]{2}{*}{ After* } & $\begin{array}{l}\text { TCAR - } \\
\text { CON } \\
(\mathrm{SCM})\end{array}$ & 1442 & 736 & 7.94 & $\begin{array}{l}\text { Below } \\
10 \\
\mathrm{ng} / \mathrm{mL}\end{array}$ & $\begin{array}{l}0.01 \mathrm{ng} / \\
\mathrm{mL}\end{array}$ \\
\hline & $\begin{array}{l}\text { TCAR - } \\
\text { CON } \\
(\mathrm{SFM})\end{array}$ & 1532 & 755 & 8.0 & $\begin{array}{l}\text { Below } \\
10 \\
\mathrm{ng} / \mathrm{mL}\end{array}$ & $\begin{array}{l}0.01 \mathrm{ng} / \\
\mathrm{mL}\end{array}$ \\
\hline
\end{tabular}

Table 3: Status of the rabies virus after purification. ${ }^{\star}$ Results are the mean values of 3 separate experiments. TCAR: Tissue Culture Anti Rabies, CON: Concentrated rabies viral harvest; SCM: Serum Contained Media; SFM: Serum Free Media.
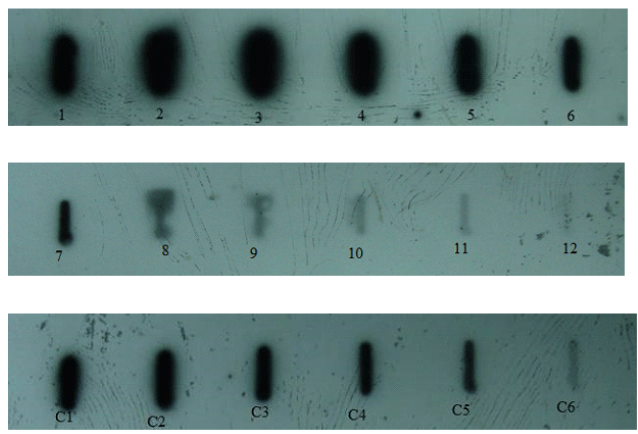

Figure 2: Slot blot hybridization for quantitative detection of affinity column purified test samples and Vero cell substrate DNA C1 to C6 DNA with $10 \mathrm{ng}, 1 \mathrm{ng}, 0.1 \mathrm{ng}, 0.01 \mathrm{ng}$, and $0.001 \mathrm{ng}$ and $0.0001 \mathrm{ng}$ dilutions respectively.

\section{Samples 1 to 12 various stages of vero cell rabies vaccine production by Cellufine Sulfate column chromatography}

1 and 2 SCM and SFM originated, concentrated and $\beta \mathrm{PL}$ inactivated rabies virus, 3 and 4 Primary run fractions of $100 \mathrm{~mm}$ $\mathrm{NaCl}, 5$ and 6 Primary run fractions of $600 \mathrm{mM} \mathrm{NaCl}, 7$ and 8 primary run fractions of $300 \mathrm{~mm} \mathrm{NaCl}, 9$ and 10 Secondary run fractions of $300 \mathrm{mM} \mathrm{NaCl}, 11$ and 12 are diafiltred $300 \mathrm{~mm}$ secondary run fractions. 
The present result supports cellufine sulfate could be an ideal matrix for rabies virus purification. The compatibility of phosphate buffer saline at $\mathrm{pH} 7.6$ worked noticeably well for rabies virus purification and the gradient buffer with varying strength of sodium chloride provided evidence of compatibility for the sample and appropriateness in eluting bound rabies virus. After purification using with cellufine sulfate affinity chromatography the HCP and host cellular DNA were found to be low. In the studies of Reap et al. for purification of alpha virus particles through cellufine sulfate matrix, eluted with $250 \mathrm{mM}$, the purity of the material was within the WHO requirements [20].

However the rabies viral protein was retained to the maximum, both in case of SCM and SFM that was analyzed by SDS-PAGE and it showed a lot of protein bands mainly in the molecular weight of 120 , 66 and 58 (KDa Figure 3) and also showed without changes of protein in SCM, SFM. Rabies virus consists of different proteins but five structural proteins are more significant [21]. Moreover the $300 \mathrm{mM}$ $\mathrm{NaCl}$ eluted primary, secondary fractions from SCM and SFM originated rabies viral proteins showed two bands, one of which correspond with $66 \mathrm{KDa}$ indicating the GI (glycoprotein $65 \mathrm{KDa}$ ). Glycoprotein is the major immunogen to which neutralizing antibodies are produced after vaccination. The main striking feature of this $300 \mathrm{~mm}$ eluted fractions was that it also showed a uniformly stained background against which proteins appeared as faint thin lines. In case of concentrated rabies viral proteins of SCM and SFM originated the lane A\& B showed smudged bands of proteins it reveals the partial purification after TFF.

\begin{tabular}{|l|l|l|l|l|l|}
\hline Vaccine details & $\begin{array}{l}\text { No. of } \\
\text { animals } \\
\text { used }\end{array}$ & $\begin{array}{l}\text { RFFIT } \\
\text { Rabies } \\
\text { IU/ml }\end{array}$ & \multicolumn{4}{|l|}{ Neutralizing antibodies in } \\
\cline { 3 - 6 } & & $\begin{array}{l}\text { 0th } \\
\text { day }\end{array}$ & $\begin{array}{l}\text { 7th } \\
\text { day }\end{array}$ & $\begin{array}{l}\text { 14th } \\
\text { day }\end{array}$ & $\begin{array}{l}\text { 21st } \\
\text { day }\end{array}$ \\
\hline $\begin{array}{l}\text { SCM originated, purified } \\
\text { pooled material of 300mM } \\
\text { fractions }\end{array}$ & 8 & $<05$ & $<05$ & 32 & $32-64$ \\
\hline $\begin{array}{l}\text { SFM originated, purified } \\
\text { pooled material of 300mM } \\
\text { fractions }\end{array}$ & 8 & $<05$ & 16 & $32-64$ & 64 \\
\hline $\begin{array}{l}\text { Local reference } \\
\text { (HO23) }\end{array}$ & 8 & $<05$ & $16-32$ & $32-64$ & 64 \\
\hline
\end{tabular}

Table 4: Immunogenicity analysis of SCM and SFM originated rabies virus after purification through cellufine sulfate affinity chromatography. Dose $1 \mathrm{ml}, \mathrm{I} / \mathrm{m}$ on days $0,7^{\text {th }}$ (booster) for both.

The SCM, SFM originated cellufine sulfate purified pooled material of $300 \mathrm{mM}$ fractions was subjected to RFFIT technique for the analysis of rabies neutralizing antibodies $\mathrm{IU} / \mathrm{ml}$ along with local reference (HO23). The seroconversion rate of guinea pigs blood samples are above $0.5 \mathrm{IU} / \mathrm{ml}$ on the $7^{\text {th }}$ day itself.

The immunogenicity of the SCM and SFM originated rabies vaccines was found to be comparable with $\mathrm{HO} 23$ that revealed in the ODD (Figure 4) [22]. The experiments of cellufine sulfate purified of vero-cell derived Japanese encephalitis vaccine by Sugawara et al., showed that almost all low-molecular weight impurities were removed by Sucrose-density gradient ultra-filtration and that the residual impurities are removed column chromatography [23].

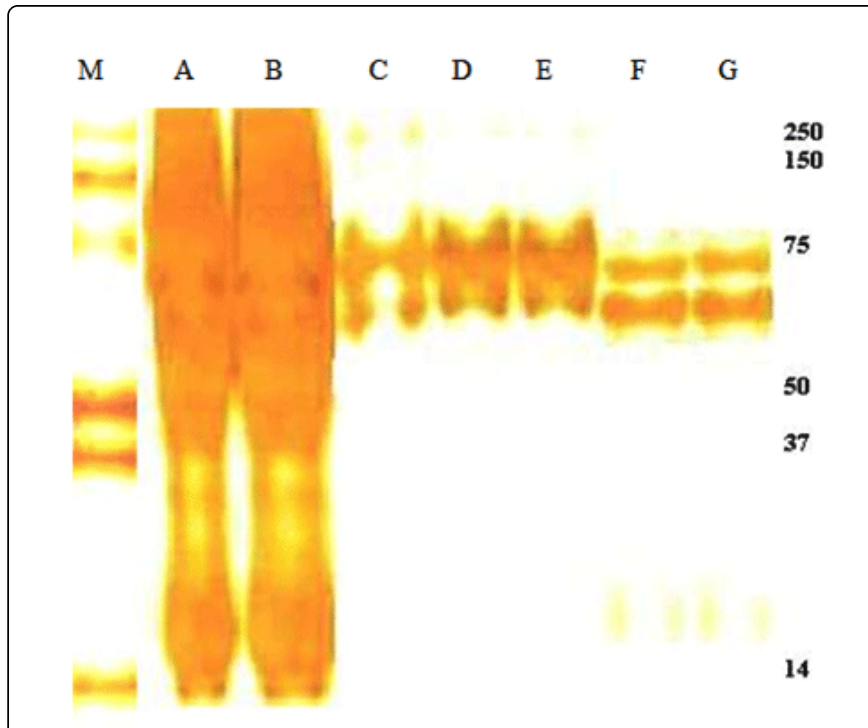

Figure 3: SDS-Polyacrylamide gel electrophoresis of different chromatographic fractions of rabies viral protein, and concentrated rabies viral protein using SCM and SFM.

M: Marker protein; A: Concentrated rabies viral protein SCM originated; B: Concentrated rabies viral protein SFM originated; C: Primary chromatographic elution $(600 \mathrm{mMNaCl})$; D: Primary chromatographic elution $(300 \mathrm{mMNaCl}) \quad(\mathrm{SCM})$; E: Primary chromatographic elution (300 $\mathrm{mMNaCl})$ (SFM); F: Secondary chromatographic elution (300 $\mathrm{mMNaCl})$ (SCM); G: Secondary chromatographic elution (300 $\mathrm{mMNaCl})(\mathrm{SFM})$.

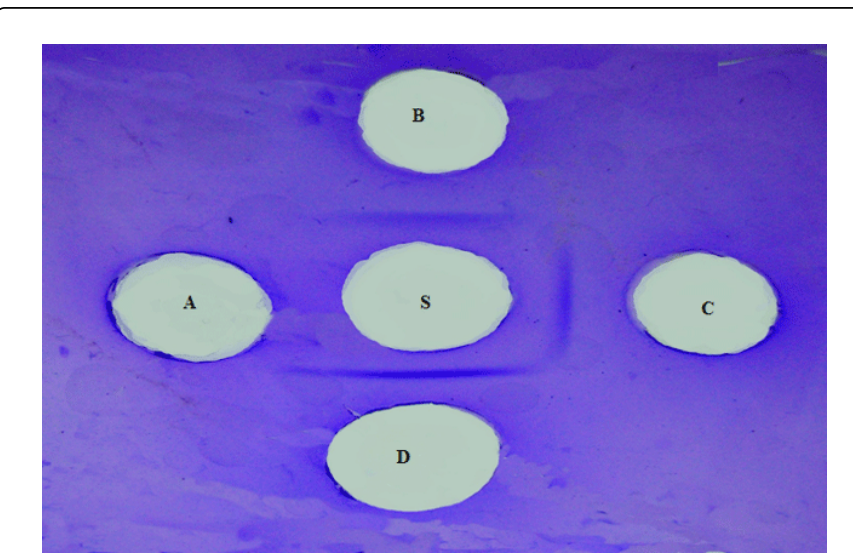

Figure 4: Ouchterlony double Immunodiffusion assay. A: Negative control; B: Guinea pig serum of SCM Originated Purified pooled material of $300 \mathrm{mM}$ fractions; C: Guinea pig serum of SFM Originated Purified pooled material of $300 \mathrm{mM}$ fractions; D: Guinea pig serum of Local reference (HO23) rabies vaccine; S: Chromatographically purified fractions (second run, $300 \mathrm{mM}$ ) of Rabies antigen.

It is an excellent alternative to sucrose gradient centrifuge and other complicated operations. It is ideal for depyrogenating virus and other microbial extracts because it does not bind endotoxins. It has been demonstrated by many workers that it can bind, concentrate and 
separate viral antigens from unwanted proteins [23]. 223 fold of viral cell proteins were eliminated during Cellufine sulfate chromatography and sepharose $6 \mathrm{FF}$ and high recovering of heamagglutinin activity and also the removal of total protein, HCP and DNA from Human influenza virus, the final purified, formulated product which fulfill with regulatory requirements for single strain influenza vaccines [24].

\section{Conclusion}

The objective of the study was to develop the alternative purification techniques for the zonal centrifugation those was used during the production processing of cell culture rabies vaccine. The content of the host cell derived DNA and contaminating proteins such as bovine serum albumin and vero cell proteins were found to be low which is quite below IP/WHO [25]. All the formulated rabies vaccines are passed $\mathrm{pH}$, sterility, avirulence and virus amplification tests for the testing of reactogenic and protection. The HCP per dose was found to be $8.5 \mathrm{ng}, 10.5 \mathrm{ng}$, $5.5 \mathrm{ng}$ and $6.5 \mathrm{ng} /$ dose for the lots $\mathrm{A}, \mathrm{B}, \mathrm{C}$ and $\mathrm{D}$ respectively against the admissible level of $50 \mathrm{ng} / \mathrm{dose}$. All the four lots contained less than $0.01 \mathrm{ng} /$ dose of residual host-cell DNA against the permissible level less than 10ng/dose.

The substrate impurities like host cellular proteins, residual cellular DNA was completely removed and it was ensured as these may lead to various types of adverse reactions. As per the regulatory norms $[5,26]$, the final vaccine product should not have $ß$-propiolactone more than 1:3500 dilution and thiomersol not more than $0.01 \% \mathrm{w} / \mathrm{v}$ to prevent adverse reactions. And also absence of non-structural and nonimmunogenic viral proteins is necessary to improve purity and efficacy of the vaccines [27].

All production parameters including the use of serum free media were optimized and standardized to produce large quantities high titer viral harvests. A new technique "Cellufine sulfate Chromatography" which has been used for other viral vaccines of both animal and man, was used in this study for optimal recovery of valuable viral protein and optimal removal of impurities, it is a simple, scalable and inexpensive technique, the results showed that the vaccines are highly immunogenic as well as the protective in mice it leads to the sufficient degree of protection after vaccination.

\section{Ethical Approval}

For conduction of all animal experiments, prior permission had been obtained from the Institution Animal Ethics committee and the animals were housed, maintained and experimented according to the institutional regulations in force.

\section{Acknowledgements}

We are thankful to the Director, Pasteur Institute of India for giving the opportunity and our sincere thanks to Mr.D.Surenderan and Mr.M.Pasupathy for their constant support and assistance to carry out the work.

\section{References}

1. Gemeiner P, Polakovic M, Mislovicová D, Stefuca V (1998) Cellulose as a (bio)affinity carrier: properties, design and applications. J Chromatogr B Biomed Sci Appl 715: 245-271.

2. Nathan SJ, Shivanandappa KC, Sundran B, Venkataramana KN, Mani KB (2008) Filtration Technique in Vaccine Manufacturing. Adv Biotech $37-41$.
3. Downing LA, Bernstein JM, Walter A (1992) Active respiratory syncytial virus purified by ion-exchange chromatography: characterization of binding and elution requirements. Journal of virological methods 38 : 215-228.

4. Icatlo FC, Kuroki M, Kobayashi C, Yokoyama H, Ikemori Y, et al. (1998) Affinity purification of Helicobacter pylori urease. Relevance to gastric mucin adherence by urease protein. J Biol Chem 273: 18130-18138.

5. IPC, Indian Pharmacopoeia (2010) Indian Pharmacopoeia Commission.

6. Jagannathan S, Chaansha S, Rajesh k, Santhiya T, Charles C, et al. (2009) Standardization and assessment of cell culture media quantities in roller poly ethylene terephthalate bottles employed in the industrial rabies viral vaccine production. Pakistan journal of biological sciences 12: 1246-1252.

7. Jagannathan S, Vijayakumar R, Rahul Gandhi P, Anandhi M, Charles C, et al. (2010) Analysis of Carbohydrates in Newly Developed Liquid State Rabies Vaccine. Journal of Microbial and Biochemical Technolnology 2: 147-151.

8. Atanasiu P (1973) Quantitative assay and potency test of antirabies serum and immunoglobulin. Monogr Ser World Health Organ : 314-318.

9. Reed LJ, Muench H (1938) A simple method of estimating fifty percent endpoints. American Journal of Epidemiology 27: 493-497.

10. Seligmann EB Jr (1973) Laboratory techniques in rabies: the NIH test for potency. Monogr Ser World Health Organ : 279-286.

11. Jagannathan S, Mani KR, Vijayakumar R, Rahul Gandhi P, Venkataramana KN (2011) Comparative analysis of magnesium chloride in recently developed liquid state rabies vaccine. International Journal of Pharma \& Bio Sciences 2: 473-479.

12. Kuwert E, Wiktor TJ, Sokol F, Koprowski H (1968) Hemagglutination by rabies virus. J Virol 2: 1381-1392.

13. Stoscheck CM, Murray PD (1990) Quantitation of protein, in Methods in Enzymology. Academic Press 50-68.

14. Laemmli UK (1970) Cleavage of structural proteins during the assembly of the head of bacteriophage T4. Nature 227: 680-685.

15. Ferguson M, Seagroatt V, Schild GC (1984) A collaborative study on the use of single radial immunodiffusion for the assay of rabies virus glycoprotein. Journal of biological standardization. 13: 283-294.

16. Ouchterlony O (1958) Diffusion-in-Gel Methods for Immunological Analysis. Karger, New York, USA.

17. Green MR, Sambrook J (2000) Molecular cloning: a laboratory manual. Cold Spring Harbor Laboratory Press, New York, USA.

18. Massari P, King CA, MacLeod H, Wetzler LM (2005) Improved purification of native meningococcal porin PorB and studies on its structure/function. Protein Expr Purif 44: 136-146.

19. Thomas JB, Ricker AS, Baer GM, Sikes RK (1965) Purification of fixed rabies virus. Virology 25: 271-275.

20. Reap EA, Morris J, Dryga SA, Maughan M, Talarico T, et al. (2007) Development and preclinical evaluation of an alphavirus replicon particle vaccine for cytomegalovirus. Vaccine 25: 7441-7449.

21. Meslin FX, Kaplan MM, Koprowski H (1996) Laboratory techniques in rabies. World Health Organization, Geneva.

22. Hilfenhaus J, Köhler R, Barth R, Majer M, Mauler R (1976) Large-scale purification of animal viruses in the RK-model zonal ultracentrifuge. I. Rabies virus. J Biol Stand 4: 263-271.

23. Sugawara K, Nishiyama K, Ishikawa Y, Abe M, Sonoda K, et al. (2002) Development of Vero cell-derived inactivated Japanese encephalitis vaccine. Biologicals 30: 303-314.

24. He C, Yang Z, Tong K (2011) Downstream processing of Vero cellderived human influenza A virus (H1N1) grown in serum-free medium. J Chromatogr A 1218: 5279-5285.

25. WHO (1973) WHO Expert Committee on Biological Standardization: twenty-fifth report. World Health Organ Tech Rep Ser 530: 1-66.

26. World Health Organization (1994) WHO Expert committee on biological standardization- Annexure 4. WHO Technical Report Series No 840, Switzerland.

27. Jagannathan S, Rahul Gandhi P, Vijayakumar R (2013) Kinetics Analysis of Beta-propiolactone with Tangential Flow Filtration (TFF) 
Citation: Selvaraj J, Raju MK, Rajendran V (2015) Analysis of Alternative Purification of Beta-Propiolactone Inactivated, Tangential Flow Filtration Concentrated Vero Cell Derived Rabies Vaccine. J Vaccines Vaccin 6: 269. doi:10.4172/2157-7560.1000269

Page 6 of 6

Concentrated Vero Cell Derived Rabies Viral Protein. Journal of Biological Sciences 13: 521-527. 